\title{
THE MORPHOLOGY AND ULTRASTRUCTURE OF THE NECTARIES OF MARROW (Cucurbita pepo L. convar. giromontiina)
}

\author{
Marta Dmitruk, Elżbieta Weryszko-Chmielewska
}

\author{
Department of Botany, University of Life Sciences in Lublin, Akademicka 15, 20-950 Lublin, Poland \\ e-mail: marta.dmitruk@up.lublin.pl
}

Received: 25.01.2013

\begin{abstract}
The present study investigated the size and structure of the nectaries in flowers of marrow - Cucurbita pepo convar. giromontiina cv. 'Weiser Busch'. The diameter and thickness of nectariferous layer were compared in female and male flowers of this taxon. The micromorphology as well as the anatomical and ultrastructural characters of the nectary from the female flower were observed using light, scanning and transmission electron microscopy. The density and size of stomata of the nectary epidermis from both types of flowers were examined using light microscopy.

The nectaries in female flowers were found to have a larger size than in male flowers. The stomata occurring in the nectary epidermis of both types of flowers have a similar size and density. We observed that nectar was released onto the surface of the nectary not only via the stomata, but also through the walls of the epidermal cells. In TEM examination, large nuclei, different-shaped plastids, ER tubules, dictyosomes, and ribosomes were observed in the nectariferous tissue cells. A large number of mitochondria accompanying the plastids were found in the parenchyma cells of the nectary. The degradation of the nectary parenchyma cells in the flowers living for about 6 hours was asynchronous.
\end{abstract}

Key words: nectary, size, micromorphology, anatomy, ultrastructure, marrow, Cucurbita pepo, flowers

\section{INTRODUCTION}

The genus Cucurbita - squash (f. Cucurbitaceae) comprises 20 species native to the tropical and subtropical regions of America. Two species: C. pepo and C. maxima, which are valued for their dietetic fruits, are most frequently grown in the world and in Poland [1]. Squash is also known as a medicinal, ornamental and honey plant. The research on nectar secretion by squash flowers shows that there is a significant difference in the amount of nectar produced between two types of flowers. Pistillate flowers produce more nectar than staminate flowers $[2,3,4]$. In the climatic conditions of Poland, squash belongs to plants that produce the largest amount of nectar per flower. According to L i p i ń s k i [5], under favourable conditions a female flower of $C$. pepo can produce up to $400 \mathrm{mg}$ of nectar. Other studies reveal that on average $135.3 \mathrm{mg}$ of nectar can be obtained from one female flower of marrow (Cucurbita pepo convar. giromotiina) [6]. Squash nectar is not very sweet and the percentage content of sugar ranges $20-30 \%$ [3,6,7,8,9,10]. Large amounts of nectar in Cucurbita flowers are produced by one of the largest nectaries. A positive correlation has been found between the amount of nectar produced and nectary size in the case of flowers of Cucurbita and Cucumis [2,4,11]

Flowers of plants of the genus Cucurbita are considered to be hemitropous with hidden nectaries, but located not very deep and accessible to insects with medium long mouthparts [3,7]. Nepi and Pacini [12] report that the nectaries in squash flowers of both sexes are dimorphous because they differ in size, position and accessibility to insects. Studies of different authors demonstrate that hypantial nectaries are found in the members of Cucurbitaceae, subfamily Cucurbitoideae. They are mesenchymatous and contain numerous stomata through which nectar is exuded $[3,13,14,15]$.

The morphology, ultrastructure and ecological characters of the nectaries of zucchini (Cucurbita pepo) were studied by different authors $[4,13]$. $\mathrm{Ne} \mathrm{pi}$ et al. [16] also investigated nectar resorption in the nectaries of C. pepo. Fahn and Sihmony [14] presented the structure and ultrastructure of the floral nectaries of Ecbalium elaterium (L.) A. Rich. Y i - B e n P e n g et al. [17] studied the ultrastructure of nectariferous tissue and nectar transport in the nectaries of Cucumis sativus. 
The aim of the present study was to investigate the structure of the nectaries during active nectar exudation in another member of Cucurbitaceae - Cucurbita pepo convar. giromontiina 'Weiser Busch'. The study covered the micromorphology, anatomy and ultrastructure of nectariferous tissues in female flowers of this plant. Moreover, the size of the nectaries in female and male flowers was compared.

\section{MATERIALS AND METHODS}

The study material consisted of male and female flowers of marrow (Cucurbita pepo L. convar. giromontiina cv. Grebenšč. 'Weiser Busch').

Hand-cut longitudinal sections of the nectaries sampled from fresh flowers collected after petal opening were made for preliminary examination. Their diameter and nectariferous tissue thickness were measured. Female flowers collected on the day of anthesis at 10.00 hours were used to examine nectary anatomy and ultrastruture.

\section{Light microscopy (LM)}

Fresh plant material was fixed in $70 \%$ ethanol. To make a comparative analysis of the number and size of stomata, semi-permanent slides of the nectary epidermis were prepared in glycerol with water.

\section{Semi-thin sections}

To prepare semi-thin sections, fragments of nectariferous tissue were fixed in $2 \%$ paraformaldehyde and $2.5 \%$ glutaraldehyde in $0.1 \mathrm{M}$ cacodylate buffer with a $\mathrm{pH}$ of 7.4 at room temperature for 2 hours, and then for 12 hours at $4{ }^{\circ} \mathrm{C}$. After the specimens were immersed in $0.1 \mathrm{M}$ cacodylate buffer at $4{ }^{\circ} \mathrm{C}$ for 24 hours and post-fixed in $1 \% \mathrm{O}_{\mathrm{S}} \mathrm{O}_{4}$, they were then transferred to redistilled water and treated with $0.5 \%$ aqueous solution of uranyl acetate. Next, the plant material was dehydrated in an alcohol series and by using increasing concentrations of propylene oxide. The nectary specimens were embedded in Spurr's low viscosity resin for 12 hours at a temperature of $70{ }^{\circ} \mathrm{C}$. The nectariferous tissue sections were stained with $1 \%$ methylene blue with $1 \%$ azur II in $1 \%$ solution of sodium tetraborate. Observations and photographs were made using a Jenaval Contrast microscope.

\section{Scanning electron microscopy (SEM)}

The surface of the nectary glands was observed by scanning electron microscopy. Nectary specimens were fixed in $4 \%$ glutaraldehyde solution in $0.1 \mathrm{M}$ cacodylate buffer with a $\mathrm{pH}$ of 7.4 at a temperature of $4{ }^{\circ} \mathrm{C}$ for 12 hours. Then, the sections were dehydrated in an acetone series and critical-point dried, and subsequently they were coated with gold in a CS 100 sputter coater. The nectary surface was examined and photographed with a BS 340 Tesla scanning electron microscope.

\section{Transmission electron microscopy (TEM)}

To examine the ultrastructure, fragments of nectariferous tissue were fixed following the above described procedure for light microscopy and they were then embedded in Spurr's low viscosity resin for 12 hours at $70{ }^{\circ} \mathrm{C}$. The material so prepared was used to make ultra-thin $(60 \mathrm{~nm})$ sections with a Reichert Ultracut S ultramicrotome. Next, they were treated with $8 \%$ uranyl acetate solution in $0.5 \%$ acetic acid and with lead citrate. Observations and photographs were made using a BS - 500 Tesla electron microscope.

\section{RESULTS}

In the climatic conditions of Lublin, flowering of marrow starts during the last 10-day period of June or the first 10-day period of July and most frequently lasts until the third 10-day period of September. The flowers started to open between 4.30 and 6.00 in the morning and they closed at 10.00-12.30. The flower life span was from 5.5 to 6.5 hours. The structure of nectaries sampled from the flowers after about 4 hours of blooming was examined in one-day flowers in which the physiological activity of the nectary glands was limited to several hours (Fig. 1 A).

\section{Nectary morphology}

In female and male flowers, the nectaries differ in position, nectar accessibility, and size. The nectaries in female flowers are an irregularly shaped fleshy trough surrounding the base of the style with an inferior ovary (Fig. $1 \mathrm{~B}, \mathrm{C}$ ). In these flowers, insects have easy access to nectar. In male flowers, the nectariferous tissue forms a layer located in the depression of the receptacle (Fig. $1 \mathrm{D}, \mathrm{E})$. It is exposed shield through the expanded and fused staminal filaments between which there are three openings that provide access to nectar.

The nectaries observed in male and female marrow flowers were orange coloured. The microscopic observations of fresh material show that this colour is determined by the presence of chromoplasts.

The measurements of the nectaries reveal that they differ both in diameter length and thickness of nectariferous tissue. The nectary in the female flower is characterized by a larger diameter and thickness of nectariferous tissue than the nectary in the male flower (Table 1). 
Table 1

The characteristic of the nectary in male and female flowers of marrow

\begin{tabular}{lcc}
\hline \multicolumn{1}{c}{ Studied features } & $\begin{array}{c}\text { Male } \\
\text { flower }\end{array}$ & $\begin{array}{c}\text { Female } \\
\text { flower }\end{array}$ \\
\hline Diameter nectary $(\mathrm{mm})$ & 9.95 & 12.93 \\
Height nectary $(\mathrm{mm})$ & 2.21 & 2.76 \\
Height of the epidermal cells $(\mu \mathrm{m})$ & 14.61 & 15.24 \\
Diameter of the parenchymal cells $(\mu \mathrm{m})$ & 17.43 & 18.38 \\
Number of stomatal cells $\left(\right.$ in $\left.1 \mathrm{~mm}^{2}\right)$ & 83.2 & 88.7 \\
Lenght of the stomatal cells $(\mu \mathrm{m})$ & 35.38 & 33.34 \\
\hline
\end{tabular}

\section{Micromorphology of nectary epidermis} (SEM)

The SEM images revealed that the nectary surface in the flowers of the studied plants was characterized by significant undulation. In dorsal view, the epidermal cells were different shaped and polygonal (Fig. $2 \mathrm{~A}$ ). The surface of the cuticle covering the outer walls of the epidermis was smooth in its major part. Fine striation was observed only in some place (Fig. 2 B). In all slides, the presence of spherical structures was found on the surface of the middle part of the nectary (Fig. 2 A-C). They were probably dried droplets of nectar. In the epidermis, there were numerous modified stomata that can be classified as actinocytic. The stomata of marrow were characterized by a very wide opening of the pore and secretion residues could be seen close to the pore (Fig. 2 A-C).

\section{Nectary anatomy}

A comparison of the number of stomata in the epidermis of the marrow nectary shows that they occur with similar density in female and male flowers. The length of stomata in the nectary epidermis of both types of flowers was also similar (Table 1). There was a large air cavity underneath the pore (Figs $3 \mathrm{~B}, \mathrm{D} ; 4 \mathrm{~F}$, $\mathrm{G})$. The guard cells had thicker inner walls, located on the cavity side (Fig. 4 G).

In cross section of the nectary, the epidermal cells had an average height of $15.24 \mathrm{~mm}$. Their outer tangential wall was thicker than the inner one (Fig. 4 $\mathrm{G})$. Droplets of secreted nectar were visible on its surface (Figs 3 B, E; 4 A-C).

Underneath the single-layered epidermis, there was a thick (about $2.7 \mathrm{~mm}$ ) tier of nectary parenchyma composed of several dozen layers of cells (Fig. 3 A) with an average diameter of $18.4 \mathrm{~mm}$. The nectary parenchyma cells differ from the subnectary parenchyma cells by their smaller size and thicker cytoplasm. In the nectary tissues sampled for examination, we observed parenchymal cells showing varying degrees of vacuolation (Fig. $3 \mathrm{C}-\mathrm{E}$ ). In some parts of the specimen, there were poorly vacuolated cells alongside cells containing very large vacuoles and small layers of parietal cytoplasm (Fig. 3 E). At other places of the specimen, we could observe cells with strongly degraded plasmatic structures next to cells in which nuclei and plastids were visible (Fig. 4 A, F). Such images are evidence of the quick, since taking place already during flowering, and asynchronous degradation of the structure of the nectary cells.

Branches of vascular bundles reach the nectary parenchyma cells located near the surface of this gland (the $3^{\text {rd }}-4^{\text {th }}$ layer) (Fig. 1 F, 4 D). The ends of these bundles were only composed of phloem elements (Fig. 4 E).

\section{Ultrastructure of nectary cells (TEM)}

\section{Epidermis}

The outer walls of the epidermis cells had a significant thickness. They were covered by a thin layer of cuticle. Nectar residues were locally observed on the surface of these walls, in particular by the radial walls of the epidermal cells underneath the stretched layer of cuticle (Fig. 5 A,B); this may suggest nectar secretion also in these places, independently of the exudation of secretion through the stomata.

The epidermal cells contained large centrally located vacuoles. The cytoplasm of these cells showed a high degree of staining, which indicates advanced senescence processes. Plastids, mitochondria and very numerous vesicles, occurring at high density by the outer cell wall, could be distinguished among the structures (Fig. 5 B).

\section{Nectary parenchyma}

The nectary parenchyma cells had thin walls (Fig. 5 B, D, E, F). Quite large air spaces formed between the cells (Figs 5 C,6 C). The cells located close to one another significantly differed in the degree of vacuolation (Fig. $5 \mathrm{C}$ ). The smaller vacuoles had different shapes (Fig. 6 A, B). Numerous plastids, mitochondria, Golgi structures, profiles of rough ER and very numerous ribosomes were observed in the cytoplasm.

The plastids varied in size and shape. No starch grains were observed in them, but in the osmophilic stroma there were bright regions surrounded with membranes or grey areas filled with a heterogeneous substance; sometimes plastoglobules were also seen (Figs 5 C, D; 6 A, B, E). In the brighter regions of the plastid stroma, few elongated or curved structures were visible; they could have been crystalline inclusions of carotenoids that give colour to the plastids and tissues of the nectary (Figs 5 C, 6 A). Some plastids showed irregular shapes typical of pleomorphic plastids (Figs 5 D; 6 A, B). Local absence of continuity of plastid envelope could be seen in many plastids 9 (Fig. 6 A, B, E). At a high level of degradation of plastids, concentric, membranous structures were observed inside them (Fig. 6 D). 
Very numerous mitochondria were located in close proximity to the plastids. The rough ER tubules were also distributed at a close distance from the pla- stids (Figs 5 C, D; 6 A, B, E). The ER profiles were often situated in the vicinity of the plasmalemma (Figs 5 E, F; 6 C).
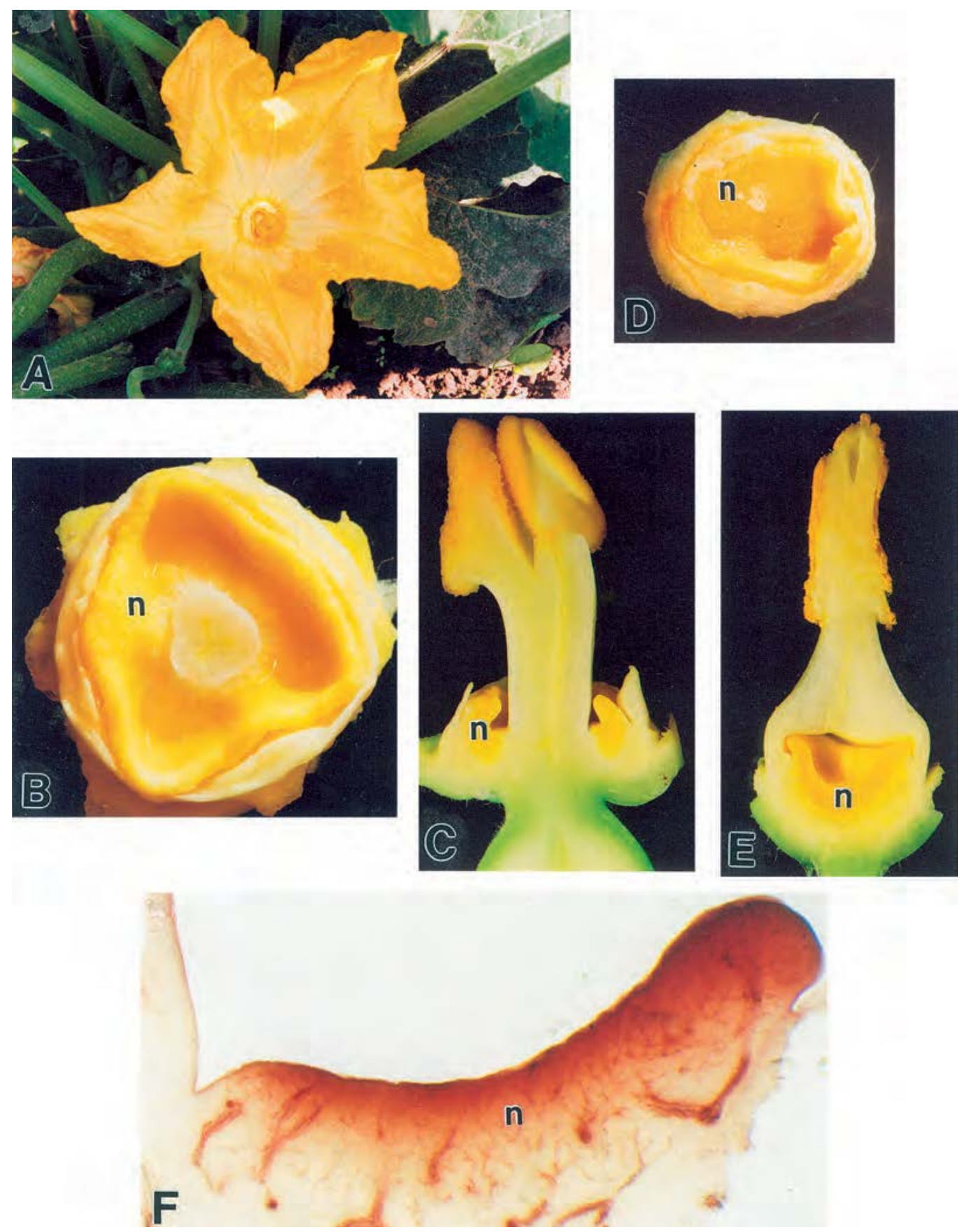

Fig. 1. Flower and the nectaries of marrow (Cucurbita pepo convar. giromontiina).

A - Female flower of marrow (x 0.7); B - Dorsal view of the nectary (n) in a female flower after removal of the perianth and style (x 3.5); C - Longitudinal section of the nectary (n) in a female flower (x 2); D - Dorsal view of the nectary (n) from a male flower (x 3.0); E - Longitudinal section of the nectary (n) in a male flower (x 3.5); F - Numerous branches of vascular bundles running from the base to the upper part of the nectary (n) (x 10). 

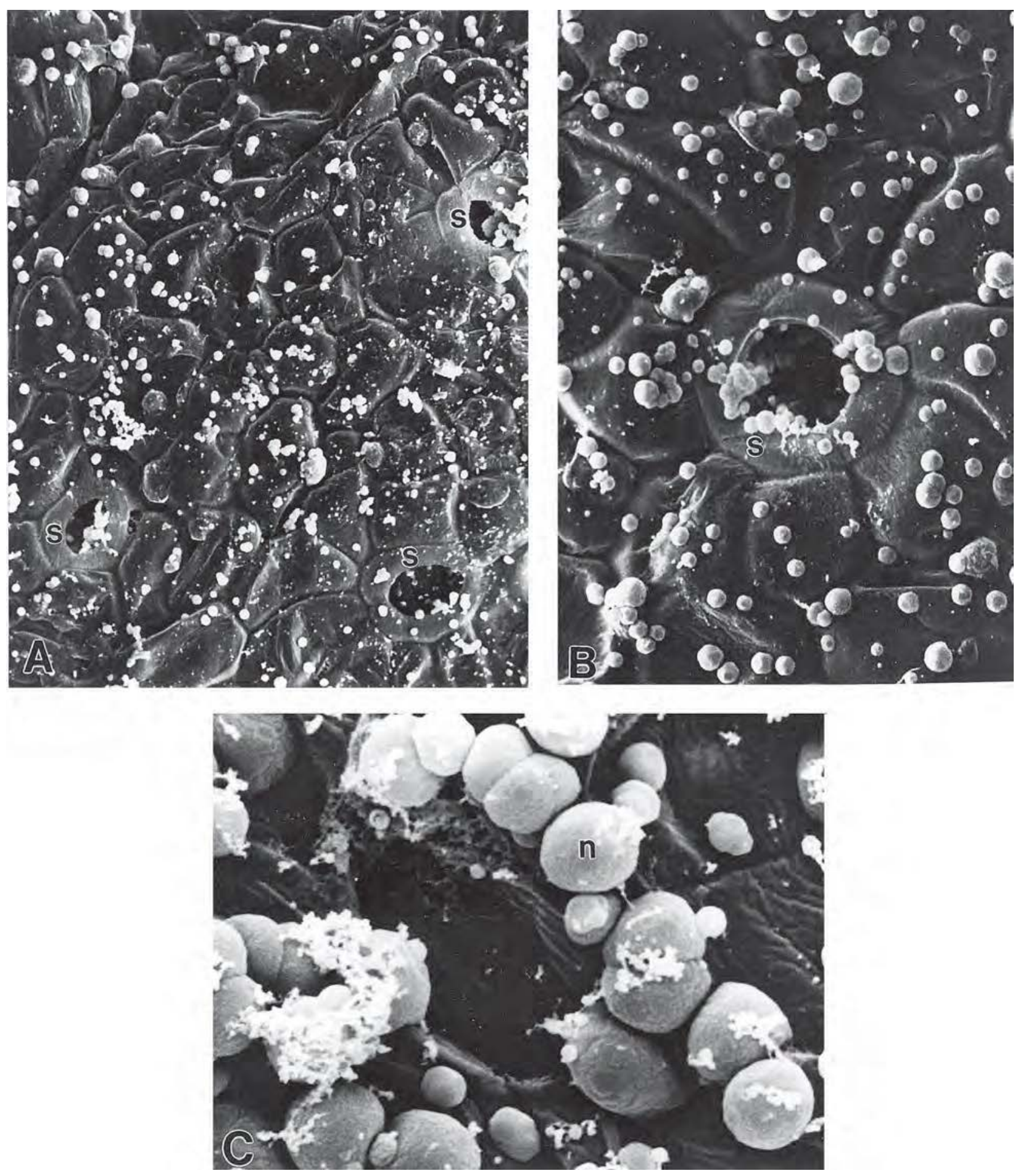

Fig. 2. Epidermal surface of a nectary of marrow (Cucurbita pepo L.) (SEM).

A - Stomata (s) with expanded pores (x 2000) are evenly distributed among the epidermal cells; B - Actinocytic stoma (s) is surrounded by radially arranged epidermal cells. Visible are bright spherical structures which are nectar residues (x 2000); C - Dried droplets of nectar (n) on the nectary surface (x 4500). 

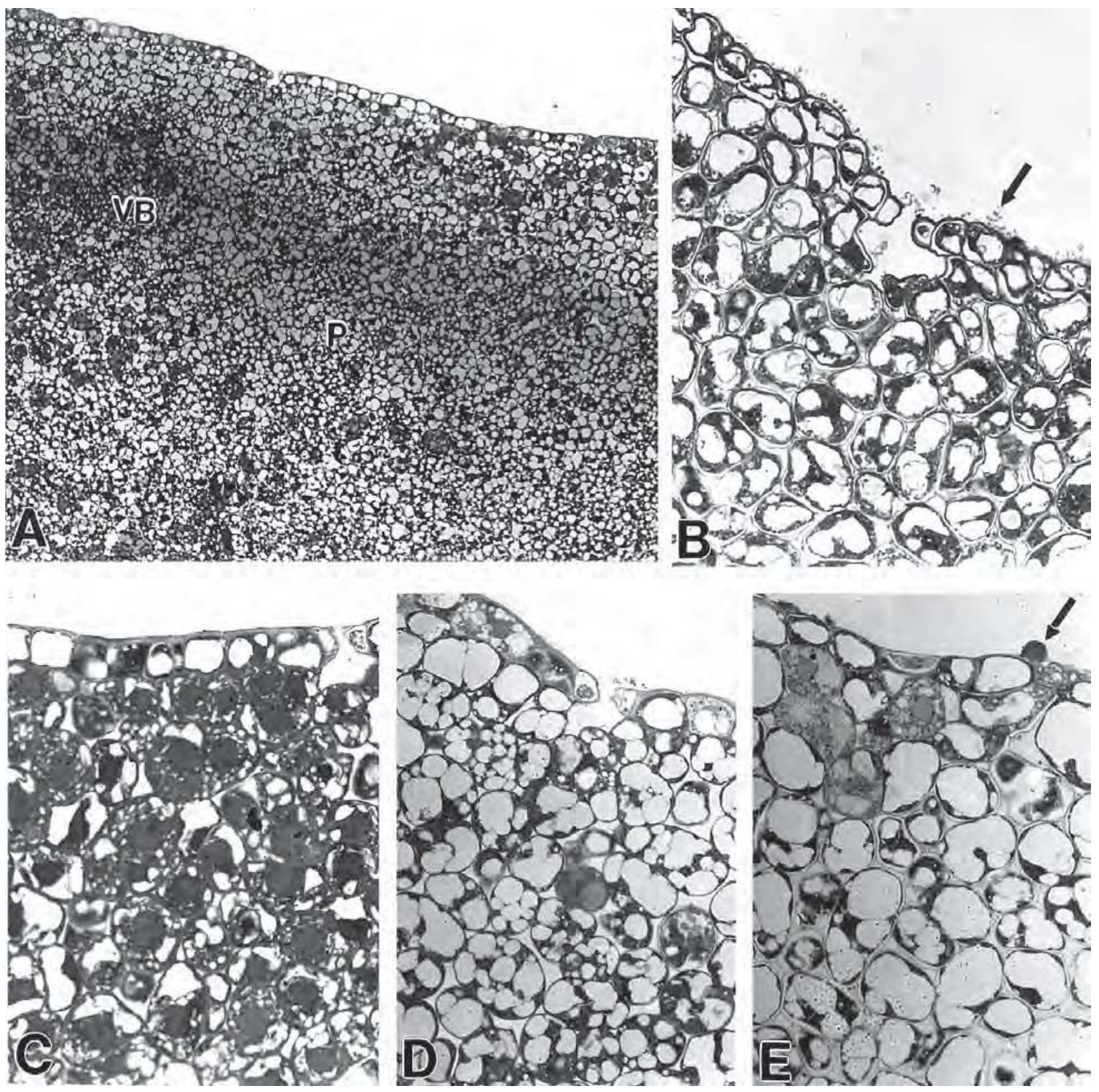

Fig. 3. Longitudinal sections of a nectary of marrow (LM).

A - The nectary tissues include the single-layered epidermis, numerous layers of parenchyma (P), and branches of vascular bundles (VB) (x 100); B - Stomata of the nectary are located in small depressions of the epidermis. Remnants of nectar (arrow) can be seen on the surface of the epidermal cell walls (x 300); C-E - Parts of the subepidermal layers of the nectary with parenchyma cells showing varying degrees of vacuolation during flowering (x 300).

Dried droplet of nectar (arrows) on the nectary surface. 

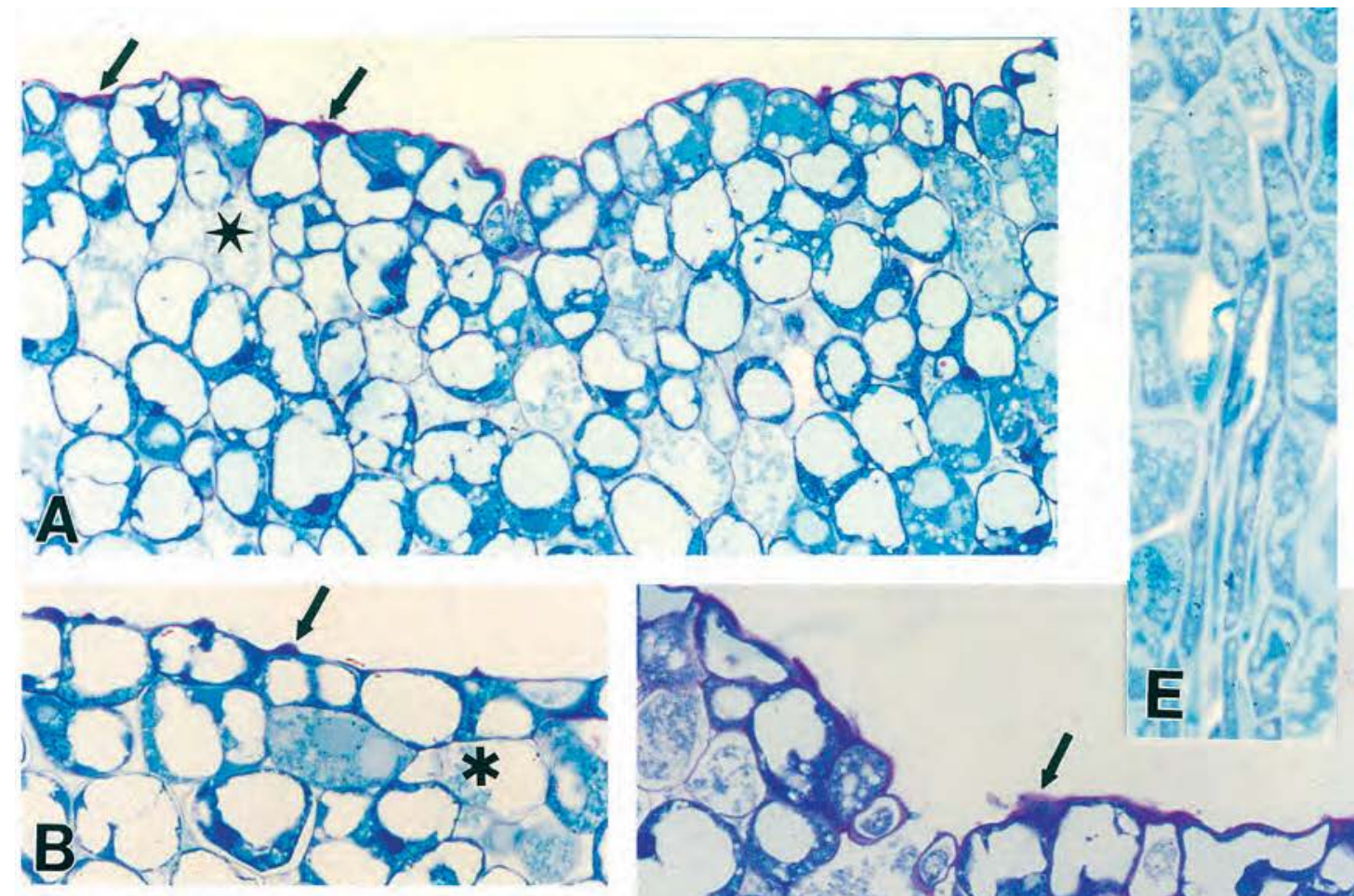

(1)
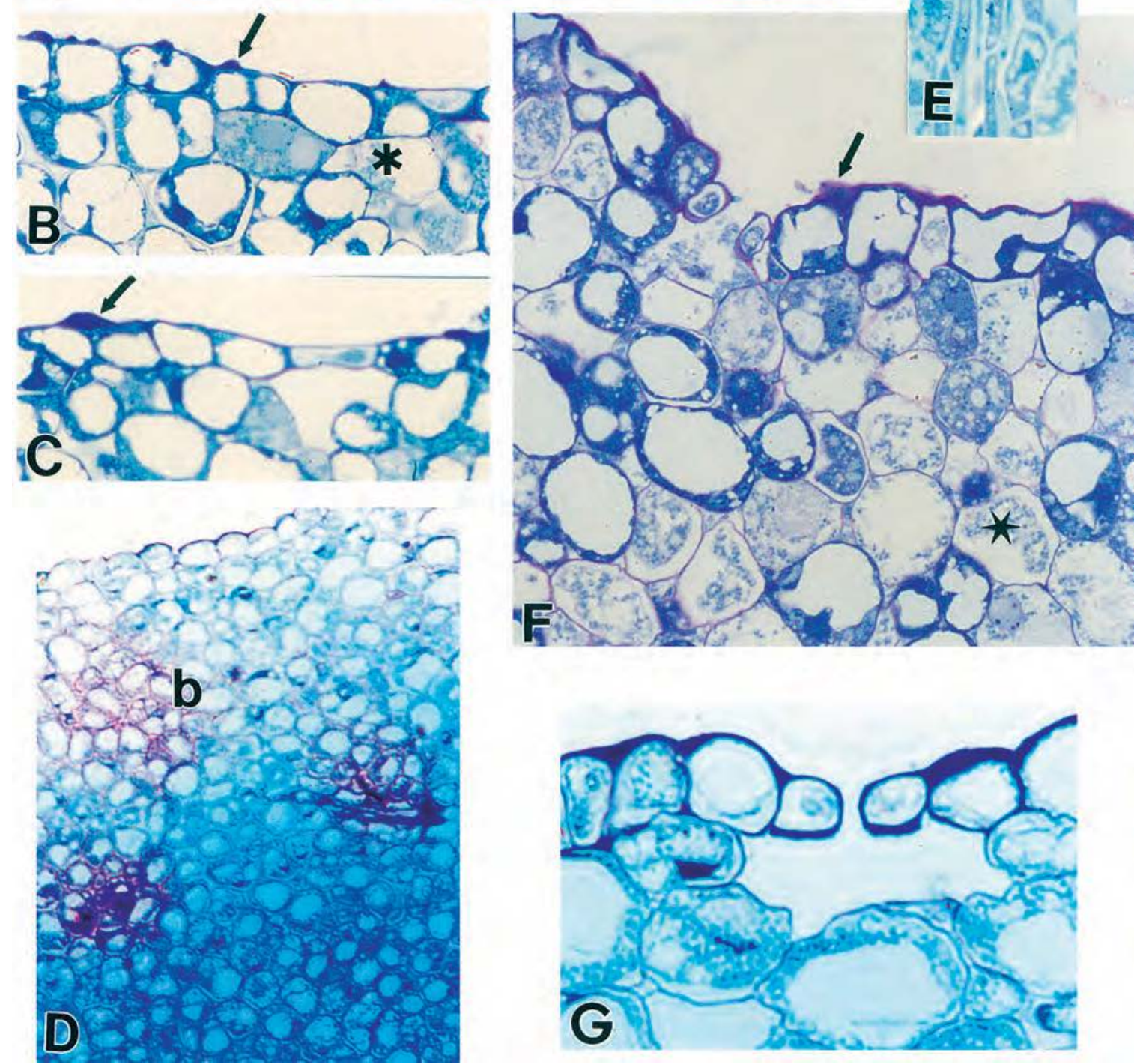

Fig. 4. Longitudinal section of a nectary of marrow - stained with methylene blue and azure II (LM).

A, B, C, F- Epidermal and parenchymal cells of a nectary showing varying degrees of vacuolation. Strong degradation of the cytoplasmic structures can be seen in some cells (asterisks). Droplets of nectar are visible on the epidermal surface (arrows) A, B, C - x 400; F - x 650; D - Portions of a nectary with visible vascular bundles (b) located close to the epidermis (x 200); $\mathrm{E}$ - Ends of a vascular bundle composed of phloem elements in the nectary parenchyma (x 650); G - Stoma in cross section of a nectary with a large air cavity (x 800). 

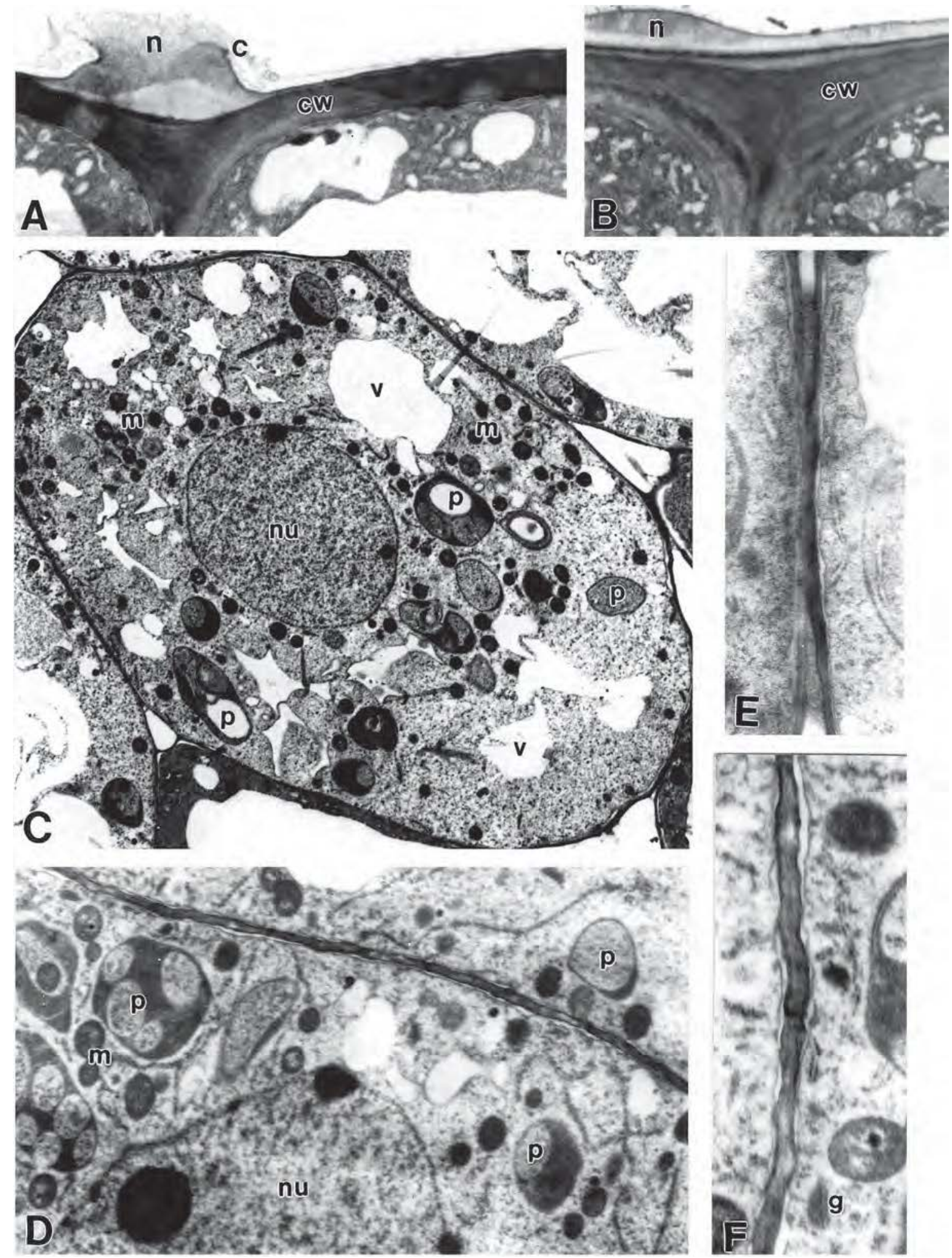

Fig. 5. Portions of epidermal and parenchymal cells of a nectary of marrow (TEM).

A, B - Cytoplasmic structures and the outer walls (cw) of the epidermal cells with visible secretion (n) underneath the cuticle layer (c) A - x 6700, B - x 10.000; C -Parenchyma cell of a nectary with a nucleus (nu), plastids (p), numerous mitochondria (m), and small vacuoles (v) (x 3000); D - Portions of parenchyma cells with a thin cell wall, numerous different-sized plastids (p), a large nucleus (nu), numerous mitochondria (m), and profiles of rough ER (x 6700); E, F - Tubular rough ER located in close vicinity to the plasmalemma; and F- Golgi structures (g) (x 15.000) 

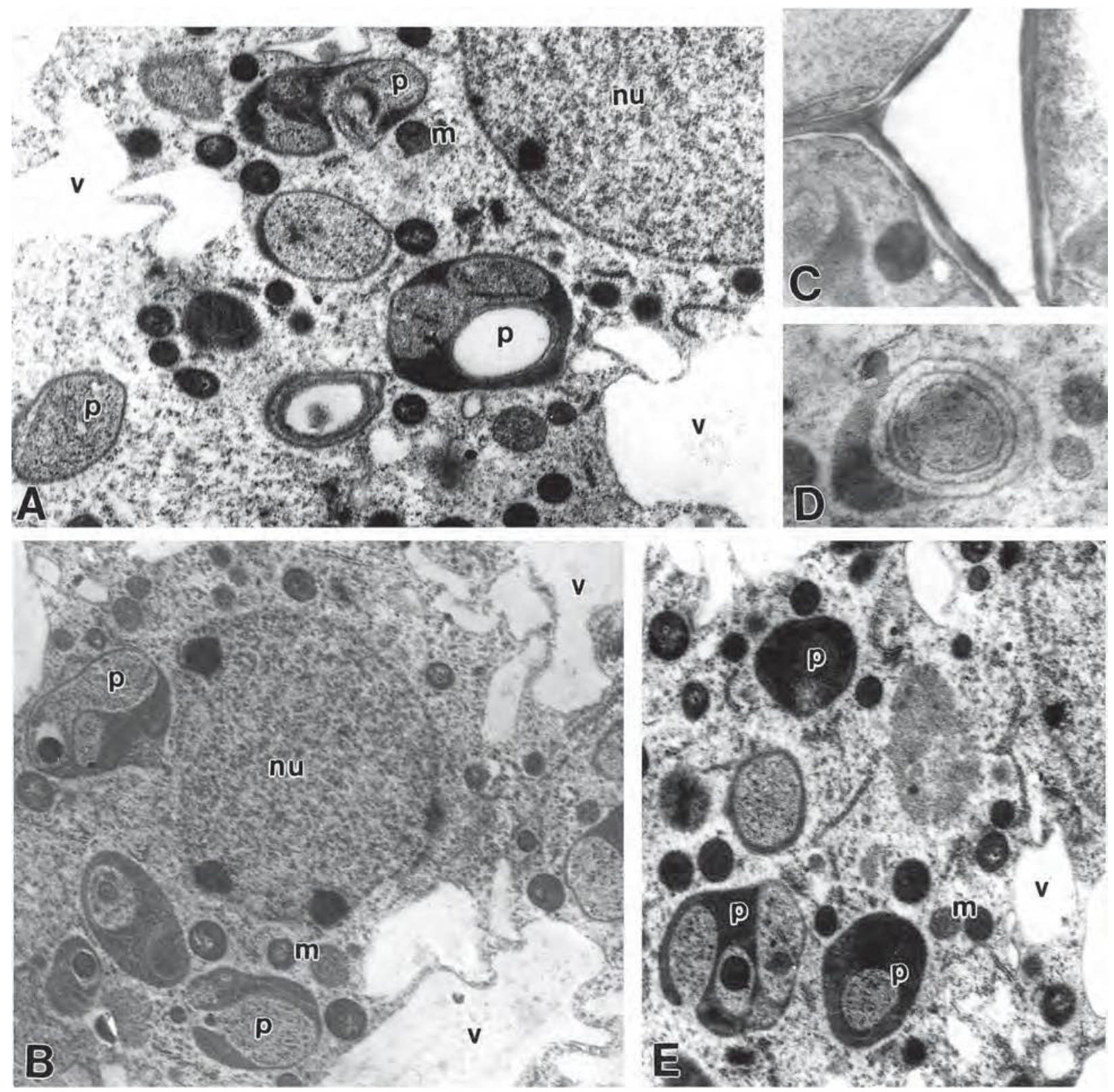

Fig. 6. Portions of parenchyma cells of a nectary of marrow (TEM).

A, B - Visible are plastids (p) and mitochondria (m) near the nucleus (nu) as well as profiles of rough ER and vacuoles (v) (x 6700); C - Parts of cells close to a intercellular space with visible tubular ER in close vicinity to the plasmalemma (x 10.000); D - Membranous, concentrically located structures in the plastid (x 10.000); E -Plastids (p) with osmophilic stroma, numerous mitochondria (m), tubular ER and vacuoles (v) can be seen in the cytoplasm (x 6700).

\section{DISCUSSION}

This study is a continuation of an earlier study on flowering biology, nectar production and insect visits to flowers of Cucurbita pepo L. and C. maxima Duch. under the conditions of central and eastern Poland $[6,10]$.

After slides were prepared following the required scanning microscopy procedure, numerous droplets of nectar, with a sugar content of about $22 \%$ [6], were observed on the surface of the nectary in fresh female flowers of marrow, C. pepo L. 'Weiser Busch'; they had the form of different sized spherical structures.

The determined number of stomata per $1 \mathrm{~mm}^{2}$ of nectary epidermis in male marrow flowers was 83.2, whereas in female flowers it was 88.7. Only one of these values is similar to the results obtained by Nepi et al. [4] for courgette plants (Cucurbita pepo L. cv. 'Greyzini) in which the number of stomata in male 
flowers was 93.9, but in female flowers it was 152.4 per $1 \mathrm{~mm}^{2}$ of epidermis.

It is known from the literature that in the members of Cucurbitaceae nectar secretion occurs through the stomata $[4,13,14]$. Our light and transmission electron microscopy observations reveal that in the nectaries of marrow nectar exudation can occur not only through the stomata, but also via the cell walls of the epidermis when the cuticle is stretched and disrupted, and we observed this many times, in particular close to the radial walls. In their discussion of the nectaries of C. pepo, $\mathrm{Nepi}$ et al. [13] considered such a possibility, but they came to a conclusion that it was unlikely. But the material presented by us clearly documents such a mode of nectar release in the nectaries of marrow. Furthermore, such a possibility is confirmed by the numerous vesicles found in the parietal cytoplasm of the epidermal cells of these nectaries, which can be seen in the photographs. On the other hand, Y i - B en Peng [17] demonstrated that in the nectaries of Cucumis sativus $\mathrm{L}$. secretion vesicles escaped to the surface through the stomalike pores of the epidermis.

Nectar is produced and secreted by C. pepo flowers only for several hours during the day $[6,10,12]$. $\mathrm{Nepi}$ et al. [13] showed fast advancing changes in the structure of these glands in material collected from zucchini nectaries before, during and after anthesis.

Numerous microscopic images made in the present study using material collected from open flowers after 4 hours of blooming indicate asynchronous senescence and degradation of nectary parenchyma cells located close to one another. Among cells with advanced disintegration of protoplasts, we observed cells with a low level of vacuolation and well-preserved organelles. Those cells might have participated in the resorption of nectar that had not been collected by insects, as described by $\mathrm{Ne} \mathrm{pi} \mathrm{at} \mathrm{al.} \mathrm{[4,13]} \mathrm{as} \mathrm{well} \mathrm{as}$ by S tpiczyńska and $\mathrm{Nepi}$ [18] in their papers.

In the sections stained with methylene blue with azur, which differentiated the stain of vascular bundles in the parenchyma, we observed that the branches of vascular bundles reached the cells located very close to the surface (the $3^{\text {rd }}-4^{\text {th }}$ layer) of the nectary. $\mathrm{Ne} \mathrm{p} \mathrm{i}$ et al. [4] also report that vascular bundles located at the base of nectariferous tissues branch out significantly near the stomata.

At the development stage of the marrow nectary which was investigated by us, we observed plastids of different, often irregular shapes; this is also frequently described in the literature [19]. We noticed that the orange colour of the nectary in marrow flowers was determined by the presence of pigments found in the plastids. In the plastid stroma, pigment bodies in a crystalline form were seen, which allows us to include these plastids in crystalline chromoplasts, one of the four types of chromoplasts that are mentioned by Evert [20].

Due to starch accumulation in the plastids of the nectary of Cucurbita pepo at the pre-secretion stage and the content of carotenoids in them, these plastids can be considered to be amylochromoplasts, similarly to the plastids in the nectaries of Nicotiana tabacum [21].

The local absence of continuity in the plastid envelopes can indicate the participation of plastids in nectar production by releasing starch hydrolisate at the earlier physiological stages of the nectary. Our observations are in agreement with the statement of $\mathrm{Yi}-\mathrm{B}$ e $\mathrm{n}$ $\mathrm{P}$ e $\mathrm{n} \mathrm{g}$ et al. [17], made based on their research on nectar production and transport in the nectaries of Cucumis sativus, that amyloplasts in the nectary parenchyma of Cucurbitaceae are nectar production centres. According to these authors, during the secretory activity of the nectary a combined amyloplast-vacuole complex is formed and it acts as the centre of dynamic nectar transformation. Fusions of plastids with the vacuole of the nectaries of Lonicera kamtschatica were observed by Weryszko-Chmielewska and Bożek [22].

In the parenchymal cells of the marrow nectary, we observed numerous mitochondria situated around the plastids. The mitochondria located close to the plastids and plasmalemma interact in nectar secretion by providing energy [23]. Many authors also report that the mitochondria in the nectariferous tissue cells form the envelope around the plastid $[24,25]$. W o j t a s z e $\mathrm{k}$ et al. [26] report that in the nectary cells mitochondria can occupy even $20 \%$ of cytoplasm volume.

\section{CONCLUSIONS}

1. The physiological and structural changes in the tissues of the nectary of marrow occurring during flowering take place asynchronously, since cells with well-preserved organelles and cells with advanced degradation of protoplasts are found close to one another.

2. Our study shows that nectar exudation in Cucurbita pepo flowers occurs not only through the stomata, but also via the cells walls of the nectary epidermis through cuticle disruption.

3. The results of our study demonstrate the participation of plastids in nectar production.

4. The branches of vascular bundles reached subepidermal layer of the nectariferous tissue.

\section{Acknowledgements}

Research supported by the Ministry of Science and Higher Education of Poland as part of the statutory activities of the Department of Botany, University of Life Sciences in Lublin. 


\section{Authors' contributions}

Concept of the study: EW-C; field research: MD; microscopical analysis: MD, EW-C; writing of the manuscript MD, EW-C; photographs: MD, EW-C.

\section{REFERENCES}

1. Szweykowska A., Szweykowski J. Słownik Botaniczy. Wiedza Powszechna, Warszawa; 2003. (in Polish)

2. Fah n A. Studies in the ecology of nectar secretion. Palest J of Bot., Jerus. Ser. 1949; 4: 207-224.

3. Maurizio A., Grafl I. Das Trachtpflanzenbuch. Nectar und Pollen die wichtigsten Nahrungsquellen der Honigbiene. Band 4. Ehernwirth Verlag München, 1969. (in German)

4. Nepi M., Pacini E., Wilemse M.T.M. Nectary biology of Cucurbita pepo: ecophysiological aspects. Acta Bot Need. 1996; 45(1): 41-54.

5. Lipiński M. Pożytki pszczele, zapylanie i miododajność roślin. Powszechne Wydawnictwo Rolnicze i Leśne, Warszawa; 1982. (in Polish)

6. Dmitruk M. Biologia kwitnienia i oblot przez owady zapylające kwiatów dyni zwyczajnej (Cucurbita pepo L.) / Flowering biology, nectar production and insect visits in Cucurbita pepo L. flowers. Acta Agrobot. 2006; 59(1): 183-197. (in Polish) http://dx.doi.org/10.5586/aa.2006.019

7. Demianowicz Z. Rośliny miododajne. Powszechne Wydawnictwo Rolnicze i Leśne, Warszawa; 1953. (in Polish)

8. Shaw T.R. The sugar concentration of the nectar of some New England honey plants. Glean Bee Cult. 1953; 81: 88-89.

9. Kaziev T.I., Seibova S.S. Nektaroproduktivnost' cvetkov predstavitelej tykvennyh v ustalovijah Azerbajdžana. XX Jubilejnyj Meždynarodnyj Kongress po Pčelovodstvu Izdatel'stvo, Moskva; 1965: 45-149. (in Russian)

10. Dmitruk M. Flowering, nectar production and insects visits in two cultivars of Cucurbita maxima Duch. flowers. Acta Agrobot. 2008; 61(1): 99-106. http://dx.doi.org/ 10.5586/aa.2008.013

11. Ashworth L., Galetto L. Differential nectar production between male and female flowers in wild cucurbit: Cucurbita maxima ssp. andreana (Cucurbitaceae). Can J. Bot. 2002; 80: 1203-1208.

12. Nepi M., Pacini E. Pollination, Pollen Viability and Pistil Receptivity in Cucurbita pepo. Ann. Bot. 1993; 72: 527-536.

13. Nepi M., Ciampolini F., Pacini E. 1996. Development and Ultractructure of Cucurbita pepo Nectaries of Male Flowers. Ann. Bot. 1996; 78: 95-104.

14. Fahn A., Simony C. Nectary structure and ultrastructure of unisexual flowers of Ecballium elaterium (L.) A. Rich (Cucurbitaceae) and their presumptive pollinators. Ann. Bot. 2001; 87:27-33.

15. B e r n a rde 11 o G. A systematic survey of floral nectaries. In: Nicolson SW, Nepi M, Pacini E (eds). Nectaries and nectar. Springer, Dordrecht, 2007.
16. Nepi M., Guarnieri M., Pacini E. Nectar secretion, reabsorption, and sugar composition in male and female flowers of Cucurbita pepo. Inf. J. Plant Sci 2001; 162: 353-358.

17. Yi-Ben Peng, Yi-Qin Li, Yu-Jin Hao, ZhiHong Xu, Shu-Nong Bai. Nectar production and trasportation in the nectaries of the female Cucumis sativus L. flower during anthesis. Protoplasma. 2004; 224: 71-78. http://dx.doi.org/10.1007/s00709-004-0051-9

18. Stpiczyńska M, Nepi M. Ecophysiological aspects of nectar reabsorbtion. Acta Agrobot. 2006; 59(1): 61-69. http://dx.doi.org/10.5586/aa.2006.006

19. Nepi M. Nectary structure and ultrastructure. [In:] S.W. Nicolson, M. Nepi, E. Pacini (eds). Nectaries and nectar. Springer, Dordrecht, 2007.

20. Evert R. F. The Protoplast: Plasma Membrane, Nucleus, and Cytoplasmic Organelles. In: Esau's Plant Anatomy. Meristems, Cells, and Tissues of the Plant Body - Their Structure, Function, and Development, John Wiley \& Sons, Inc. New Jersey, 2006.

21. Thornburg R. Molecular biology of the Nicotiana floral nectary. [In:] S.W. Nicolson, M. Nepi, E. Pacini (eds), Nectaries and nectar. Springer, Dordrecht, 2007.

22. Weryszko-Cmmielewska E, Bożek M. Structure of trichomatous nectaries in flowers of Lonicera kamtschatica (Sevast.) Pojark. Acta Agrobot. 2008; 61(1): 13-26. http://dx.doi.org/10.5586/aa.2008.002

23. Paiva E.A.S., Machado S.R. The floral nectary of Hymenaea stigonocarpa (Fabaceae, Caesalpinioideae): structural aspects during floral development. Ann. Bot. 2008; 101(1): 125-133.

24. Wist T.J., Davis A.R. Floral nectar production and nectary anatomy and ultrastructure of Echinacea purpurea (Asteraceae). Ann. Bot 2006; 97(2): 177-193. http://dx.doi. org/10.1093/aob/mcj027

25. Chwil M., Chwil S. Micromorphology and ultrastructure of the floral nectaries of Polemonium caeruleum L. (Polemoniaceae). Protoplasma, 2012; 249(4): 1059-69. http://dx.doi.org/10.1007/s00709-011-0341-y.

26. Wojtaszek P., Woźny A., Ratajczak L. Biologia komórki roślinnej. Powszechne Wydawnictwo Naukowe, Warszawa; 2006. (in Polish)

\section{Morfologia i ultrastruktura nektarników kabaczka (Cucurbita pepo L. convar. giromontiina)}

\section{Streszczenie}

W pracy badano wielkość oraz strukturę nektarników w kwiatach kabaczka - Cucurbita pepo convar. giromontiina cv. 'Weiser Busch'. Porównano średnicę i grubość warstwy nektarnika w kwiatach żeńskich i męskich tego taksonu. Przy pomocy mikroskopii świetlnej, skaningowej i transmisyjnej elektronowej 
badano mikromorfologię oraz cechy anatomiczne i ultrastrukturalne nektarnika, pochodzącego z kwiatu żeńskiego. Zagęszczenie i wielkość aparatów szparkowych w epidermie nektarników w obu typach kwiatów badano w mikroskopie świetlnym.

Stwierdzono, że nektarniki w kwiatach żeńskich mają większe rozmiary niż w męskich. Występujące w epidermie nektarników aparaty szparkowe w obu typach kwiatów mają podobną wielkość i występują w zbliżonym zagęszczeniu. Zaobserwowaliśmy, że uwalnianie nektaru na powierzchnię nektar- nika zachodzi nie tylko za pośrednictwem aparatów szparkowych, lecz także przez ściany komórek epidermy. W komórkach tkanki nektaronośnej obserwowano w TEM duże jądra komórkowe, różnokształtne plastydy, liczne mitochondria, kanaliki ER, diktiosomy i rybosomy. W komórkach tych zarejestrowano dużą liczbę mitochondriów towarzyszących plastydom. W plastydach zanotowano lokalny brak ciągłości otoczki. Degradacja komórek parenchymy nektarnika w kwiatach żyjących około 6 godzin odbywała się niesynchronicznie.

Handling Editor: Elżbieta Pogroszewska

This is an Open Access digital version of the article distributed under the terms of the Creative Commons Attribution 3.0 License (creativecommons.org/licenses/by/3.0/), which permits redistribution, commercial and non-commercial, provided that the article is properly cited.

CThe Author(s) 2013 Published by Polish Botanical Society 